\title{
Performance Evaluation of the Head Master of Madrasah Tsanawiyah State Jambi City
}

\author{
Risnita Risnita* \\ UIN Sulthan Thaha Saifuddin Jambi \\ Jambi, Indonesia \\ *risnita@gmail.com
}

\author{
Rulitawati Rulitawati \\ University of Muhammadiyah Palembang \\ ita.ilet44@gmail.com
}

\author{
Ifa Pohan \\ IAI Yasni Muara Bungo \\ iffa_iconia@yahoo.co.id
}

\begin{abstract}
The study aims to find out and evaluate the performance of the headmaster of the State Madrasah Tsanawiyah (MTsN) in the city of Jambi. This is evaluative research which using a quantitative approach. The evaluation model used is the discrepancy evaluation model. Data collection instruments using the observation guide. The results showed that the level of performance of Madrasah Tsanawiyah principals in Jambi City had not reached the maximum level of performance. MTsN Sijenjang received the lowest score of 24 with an achievement rate of $60 \%$ and the category is quite good. MTsN Kenali Besar received the highest score of 31 with an achievement rate of $77.5 \%$ and a good category. These results indicate that the performance of MTsN principals has not been optimally met according to School Principal Performance indicators.
\end{abstract}

Keywords: evaluation, performance, principal

\section{INTRODUCTION}

Human resource development, which is an integral part of the national development program, needs serious attention and priority to build professional human qualities as competent education personnel, and produce junior high school graduates who are ready to use, in line with improving the quality of school graduates the first intermediate will emerge the faithful and devout state apparatus have the quality in supporting national development that is capable of facing multi-complex challenges and problems.

Quality human resources can be prepared through the organization of school / madrasah educational institutions as providers of formal education. Madrasah Tsanawiyah State of Jambi City has gained public trust in preparing and delivering generations of the nation's children to be able to compete in global competition that increasingly feels the impact on various activities of community life [1].

Education is an activity that consists of interactions between students and educators as well as various educational sources. Interaction between students and educators and educational resources can take place in social situations (education), teaching, training, and guidance [2]. There are at least four important educational objectives, namely: 1). development of aspects of personality, 2). community development skills, 3). development of continuing study skills, and 4). skills development and readiness to work. The importance of this education must be considered in order to create a quality state development, so that the implementation of education must continue to be improved. Education is a system of educating the nation [3].

In realizing the objectives of national education, it is necessary to have an educational institution which is a place for the educational process. Educational institutions are divided into three forms, namely formal, non-formal, and informal. Formal education institutions are often referred to as schools, while non-formal and informal institutions are called nonschool educational institutions. School is an organization which is a social system. To achieve educational goals, schools must be effective in terms of leadership, teachers, students, learning activities, learning climate and the involvement of parents and community members.

\section{THEORETICAL BASIS}

\section{A. School Principal Performance Evaluation}

In realizing the objectives of national education, it is necessary to have an educational institution which is a place for the educational process. Educational institutions are divided into three forms, namely formal, non-formal, and informal. Formal education institutions are often referred to as schools, while non-formal and informal institutions are called nonschool educational institutions. School is an organization which is a social system. To achieve educational goals, schools must be effective in terms of leadership, teachers, students, learning activities, learning climate and the involvement of parents and community members. 
The success of the leadership of a headmaster can be measured through its performance. Wilson defines performance (performance) is the result of work achieved by someone based on job requirements [4]. A job has certain requirements to be done in achieving goals which are also called job standards. Performance standards are the level at which a particular job is expected to be completed, and is a comparison of the goals or targets to be achieved. Job results are the results obtained by an employee in doing work according to job requirements or performance standards. One of informant said to be successful in carrying out their work or have good performance, if the work results obtained are higher than the work standard. Further Wilson said that performance appraisal is a process carried out by the organization to evaluate or assess the success of employees in carrying out their duties [4].

Colquitt's performance is defined as "the value of the set of employee behaviors that contribute, either positively or negatively to organizational goal accomplishment". The value of a set of employee behaviors should contribute either positively or negatively to the fulfillment of organizational goals [5]. According to him, performance is determined by three factors: 1) task performance is influenced by routine and adaptation factors, 2). loyalty ship behavior (citizen ship behavior) is influenced by interpersonal factors and organizational factors, 3) counter-productive behaviors are influenced by nature deviation factors, production deviation factors, political deviation factors and personal aggression factors.

\section{RESEARCH METHOD}

Based on the title and focus of existing research, this study is included in the type of evaluative research. Evaluative research is a design and evaluation procedure in collecting and analyzing data systematically to determine the value or benefits of a practice in this case specifically educational practice [6]. The purpose of this research is to find out and evaluate the performance of the Headmaster of Madrasah Tsanawiyah State in the City of Jambi.

In this study, a quantitative approach was chosen to find out the performance of the headmaster of Madrasah Tsanawiyah State. Quantitative approaches are used because data analysis is quantitative (numerical). This study uses a discrepancy evaluation model. The evaluation process using this model is looking for gaps between standards (the conditions that should be) and the actual conditions and then the two are compared.

The research sites were conducted at MTsN Kenali Besar, MTsN Olak Kemang, MTsN East Jambi, MTsN Sijenjang and MTsN Talang Bakung. Totaling 5 MTsN. The time of this evaluative study was carried out from the beginning of February until the end of April 2019. The research subjects in this study were the principals at the MTsN Jambi City. According to observations made by researchers, there were 5 madrasa principals spread in 5 state MTs in Jambi City so that the total subjects in this study were 5 people. Suharsimi explains that if subjects are less than 100, it is better to take all of them so that the research is population research [7].
Data collection techniques used in this study were observation. In this research the researcher directly observes the research subject, so the observer is the researcher himself. The researcher uses an observation sheet in the form of a suitable list as an observation guide when conducting research on research subjects. Researchers will put a checklist $(\sqrt{ })$ on the choice of rating scale that is Very Good (SB), Good (B), Good Enough (CB) Not Good (KB) and Very Not Good (STB) "Yes". With a SB score of $5, \mathrm{~B}=4, \mathrm{CB}=3, \mathrm{~KB}=2, \mathrm{STB}=1$ (see Table 1).

The instrument used in this study was the performance appraisal instrument for principals / madrasas, which was compiled based on performance indicators for principals / madrasas, with indicators of: 1) Personality Integrity, 2) Managerial, 3). Supervision, 4). Social, 5) Work results. Furthermore, this instrument is then processed as an observation sheet. On the observation sheet the researchers only need to put a check mark in the column that has been provided with the provisions that have been set previously.

Analysis of the data used in this research is quantitative descriptive analysis. This analysis is used to determine the percentage of madrasa head performance using statistics. To determine the percentage of performance of madrasah principals, a score is calculated, which is then interpreted using the following formula and intervals.

$$
\text { Percentage }(\%)=\frac{\text { data collection value }}{\text { Total Value }} \times 100 \%
$$

TABLE I. SCORING INTERPRETATION CRITERIA

\begin{tabular}{|l|l|}
\hline \multicolumn{1}{|c|}{ Percentage } & \multicolumn{1}{c|}{ Category } \\
\hline $81-100$ & Very good \\
\hline $61-80$ & Good \\
\hline $41-60$ & Good enough \\
\hline $21-40$ & Less good = not good \\
\hline $0-20$ & Very low \\
\hline
\end{tabular}

\section{RESEARCH RESULT}

The research data that have been obtained are then processed by scoring so that the criteria of each Madrasah head are known. MTsN Kenali Besar, MTsN Olak Kemang, MTsN East Jambi, and MTsN Talang Bakung have different performance scores. MTsN Head Recognized Great $=31$, MTsN Olak Kemang head $=29.2$, MTsN East Jambi head = 27.6, Sijenjang MTsN = 24 and MTsN Talang Bakung head = 26.8. The performances of Madrasah Heads of MTsN Kenali Besar, Olak Kemang, Sijenjang, Jambi Timur, and Talang Bakung are presented in Table 2-6, respectively. The recapitulation of the performance score is provided in Table 7.

Performance evaluation (performance appraisal) is very important to assess an organization in producing public services Performance evaluation and helps leaders to make decisions in policies the value generated from evaluations makes a policy useful for public services. Nasrullah said performance evaluation is a method and process of evaluating and carrying out the tasks of a person or group of people working units in a school or organization in accordance with the performance standards or goals that have been set in 
advance. Evaluation is the fairest way of giving rewards or rewards to workers [8]. The purpose of performance evaluation is to ensure the achievement of school goals and objectives and also to find out the position of the school and the level of achievement of school targets, especially to find out if there are delays or deviations to be corrected, so that the goals or objectives are achieved. While Sudarwan Danim said that the definition of evaluation (evaluating) is [9]: "The process of measuring and comparing the results of work in fact achieved with the results that should be".

TABLE II. Madrasah HeAd Performance of MTsN Kenali Besar

\begin{tabular}{|l|l|l|l|l|}
\hline No & Indicator & $\begin{array}{c}\text { Number of } \\
\text { values }\end{array}$ & $\begin{array}{l}\text { Achievement } \\
\text { level }\end{array}$ & category \\
\hline 1 & $\begin{array}{l}\text { Personality } \\
\text { integrity }\end{array}$ & 31 & 77,5 & B \\
\hline 2 & Supervision & 31 & 77,5 & B \\
\hline 3 & Managerial & 31 & 77,5 & B \\
\hline 4 & Social & 32 & 80 & SB \\
\hline 5 & Work result & 30 & 75 & B \\
\hline & & 31 & 77,5 & B \\
\hline
\end{tabular}

TABLE III. MAdarasah HEAd PERformance OF MTSN OlaK KEMANG

\begin{tabular}{|l|l|l|l|l|}
\hline No & Indicator & $\begin{array}{c}\text { Number of } \\
\text { values }\end{array}$ & $\begin{array}{c}\text { Achievement } \\
\text { level }\end{array}$ & category \\
\hline 1 & $\begin{array}{l}\text { Personality } \\
\text { integrity }\end{array}$ & 30 & 75 & B \\
\hline 2 & Supervision & 28 & 70 & B \\
\hline 3 & Managerial & 30 & 75 & B \\
\hline 4 & Social & 31 & 77,5 & B \\
\hline 5 & Work result & 32 & 80 & SB \\
\hline & & 30,2 & 75,5 & B \\
\hline
\end{tabular}

TABLE IV. MADARASAH HEAD PERFormance OF MTSN SiJENJANG

\begin{tabular}{|l|l|l|l|l|}
\hline No & \multicolumn{1}{|c|}{ Indicator } & $\begin{array}{c}\text { Number of } \\
\text { values }\end{array}$ & $\begin{array}{c}\text { Achievement } \\
\text { level }\end{array}$ & category \\
\hline 1 & $\begin{array}{l}\text { Personality } \\
\text { integrity }\end{array}$ & 30 & 75 & B \\
\hline 2 & Supervision & 30 & 75 & B \\
\hline 3 & Managerial & 30 & 75 & B \\
\hline 4 & Social & 31 & 77,5 & B \\
\hline 5 & Work result & 32 & 80 & SB \\
\hline
\end{tabular}

TABLE V. Madrasah HeAd Performance of MTsN Jambi Timur

\begin{tabular}{|l|l|l|l|l|}
\hline No & Indicator & $\begin{array}{c}\text { Number of } \\
\text { Values }\end{array}$ & $\begin{array}{c}\text { Achievement } \\
\text { level }\end{array}$ & category \\
\hline 1 & $\begin{array}{l}\text { Personality } \\
\text { integrity }\end{array}$ & 29 & 72,5 & B \\
\hline 2 & Supervision & 28 & 70 & B \\
\hline 3 & Managerial & 28 & 70 & B \\
\hline 4 & Social & 25 & 62,5 & B \\
\hline 5 & Work result & 28 & 70 & B \\
\hline
\end{tabular}

TABLE VI. MadRasah HeAd Performance OF MTsN TALANG BAKUNG

\begin{tabular}{|l|l|l|l|l|}
\hline No & Indicator & $\begin{array}{c}\text { Number of } \\
\text { values }\end{array}$ & $\begin{array}{l}\text { Achievemen } \\
\text { t level }\end{array}$ & category \\
\hline 1 & $\begin{array}{l}\text { Personality } \\
\text { integrity }\end{array}$ & 28 & 70 & B \\
\hline 2 & Supervision & 26 & 65 & B \\
\hline 3 & Managerial & 27 & 67,5 & B \\
\hline 4 & Social & 24 & 60 & B \\
\hline 5 & Work result & 29 & 72,5 & B \\
\hline
\end{tabular}

TABLE VII. RECAPITULATION OF SCHOOL PRINCIPAL PERFoRMANCE SCORE

\begin{tabular}{|l|l|l|l|l|l|l|}
\hline No & Note & $\begin{array}{c}\text { MTsN } \\
\text { KB }\end{array}$ & $\begin{array}{c}\text { MTsN } \\
\text { OK }\end{array}$ & $\begin{array}{c}\text { MTsN } \\
\text { SJG }\end{array}$ & MTsN JT MTsN TB \\
\hline 1 & $\begin{array}{l}\text { Number } \\
\text { of values }\end{array}$ & 31 & 29,2 & 24 & 27,6 & 26,8 \\
\hline 2 & $\begin{array}{l}\text { Level of } \\
\text { achievem } \\
\text { ent }\end{array}$ & $77,5 \%$ & $70 \%$ & 60 & 69 & 67 \\
\hline 3 & category & Good & Good & $\begin{array}{l}\text { Good } \\
\text { enough }\end{array}$ & Good & Good \\
\hline
\end{tabular}

The opinion above can be obtained by the description that evaluation is an activity carried out to measure and compare the results of the implementation of activities that have been achieved with the results that should be according to plan, so that information is obtained about the value or benefits of the policy results, and can be improved if deviations occur inside it. Performance is the result of quality and quantity of work achieved by an employee in carrying out their duties in accordance with the responsibilities given to him. Bernardin and Russel say Performance is defined as the record of outcomes produced on a specified job function or activity during a specific time period. Whereas Robbin said Performance as a function of interaction between ability $($ Ability = A), Motivation (Motivation = M) and opportunity $($ Opportunity $=\mathrm{O})$ or Performance $=f(\mathrm{~A} \times \mathrm{M}$ x O$)$; That is; Performance is a function of ability, motivation, and opportunity [10].

Based on the opinion above, the performance evaluation is a process of appraisal performance appraisal carried out to see the responsibilities of his work every day whether there is an increase or decrease so that the leader can provide a supporting motivation to see the performance of the apparatus in the future. Evaluation must often be done so that the problems faced can be known and sought a good solution. "School principals are teachers who have additional duties as school principals. The complexity of school assignments makes it impossible for the institution to run well without a professional and innovative-minded headmaster.

Based on the research results, the suggestion that can be given includes The Office of the Ministry of Religion of the City of Jambi must fully support all Madrasa programs to improve the quality of learning.

\section{CONCLUSION}

The results of the study indicate that the performance of MTsN heads is already in the good and quite good category. 
[4] Wibowo, Performance Management. Jakarta: Raja Grafindo Persada, 2017.

The lowest headmaster performance level is MTsN Sijenjang with a score of 24 with an achievement level of $60 \%$, while the highest level of madrasah headmaster's performance is MTsN with a score of 31 with an achievement level of $77.5 \%$. Overall it can be concluded that some performance of the headmasters of the MTsN in Jambi City has not met the performance indicators of Madrasah heads.

\section{REFERENCES}

[1] Supardi, Teacher Performance. Jakarta, Raja Grafindo, Cet. 2, 2014.

[2] N.S. Sukmadinata, Educational research methods. Bandung: PT. Remaja Rosdakarya, 2010.

[3] Law on Education, About Teachers and Lecturers, 2003.

[5] A.J. Colquitt, J.A. LePine, and M.J. Wesson, Organizational Behavior Improving Performance, Commitment in the Work Place. New York: McGraw-Hill Company, 2009, Fourth Edition

[6] S. Arikunto and L. Yuliana, Management Education. Yogyakarta: ditya Media, 2009

[7] Supardi, Teacher Performance. Jakarta: Grafindo, 2016.

[8] N. Nursam, Journal of Islamic Education Management, vol, 2, no. 2 Oktober 2017.

[9] S. Danim, Professionalism and Professional Ethics of Teachers. Jakarta: Rineka Cipta, 2010.

[10] S.P. Robbins and A. Timothy, Judge Organizational Behavior. Jakarta: Salemba Empat, 2016 